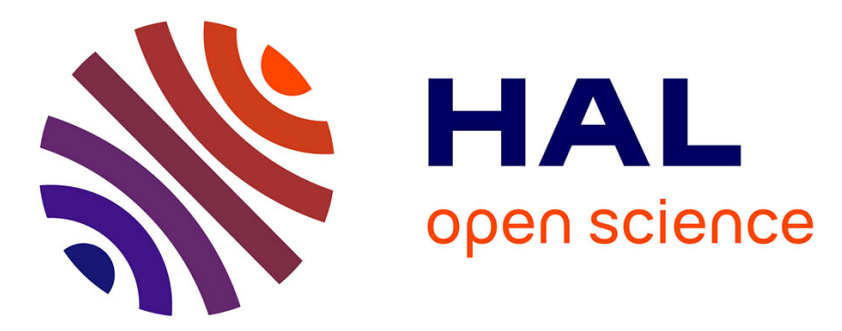

\title{
Fischer 344 Rat: A Preclinical Model for Epithelial Ovarian Cancer Folate-Targeted Therapy
}

Henri Azais, Gurvan Queniat, Caroline Bonner, Olivier Kerdraon, Meryem

Tardivel, Bertrand Leroux, Céline Frochot, Nacim Betrouni, Pierre Collinet, Serge Mordon

\section{To cite this version:}

Henri Azais, Gurvan Queniat, Caroline Bonner, Olivier Kerdraon, Meryem Tardivel, et al.. Fischer 344 Rat: A Preclinical Model for Epithelial Ovarian Cancer Folate-Targeted Therapy. International Journal of Gynecological Cancer, 2015, pp.1/7. 10.1097/IGC.0000000000000497 . hal-01183323

\section{HAL Id: hal-01183323 \\ https://hal.science/hal-01183323}

Submitted on 7 Sep 2015

HAL is a multi-disciplinary open access archive for the deposit and dissemination of scientific research documents, whether they are published or not. The documents may come from teaching and research institutions in France or abroad, or from public or private research centers.
L'archive ouverte pluridisciplinaire $\mathbf{H A L}$, est destinée au dépôt et à la diffusion de documents scientifiques de niveau recherche, publiés ou non, émanant des établissements d'enseignement et de recherche français ou étrangers, des laboratoires publics ou privés. 


\section{Fischer 344 rat is a validated animal model to study folate targeted therapy of advanced epithelial ovarian cancer.}

Azaïs Henri ${ }^{1,2}$, Queniat Gurvan ${ }^{3}$, Bonner Caroline ${ }^{3}$, Kerdraon Olivier ${ }^{4}$, Tardivel Meryem ${ }^{5}$, Leroux Bertrand ${ }^{1}$, Céline Frochot ${ }^{6}$, Betrouni Nacim ${ }^{1}$, Collinet Pierre ${ }^{1,2}$, Mordon Serge ${ }^{1}$.

1- INSERM, U703, Univ Lille Nord de France, Lille, France.

2- Department of gynecology, University of Lille, , Lille, France

3- European Genomic Institute for Diabetes, FR 3508, FR 3508 F-59000 Lille, France

4- Centre de biologie-pathologie, University of Lille, , Lille, France.

5- Plate-forme d'imagerie cellulaire. Pôle recherche, University of Lille, , France.

6- Laboratoire Réactions et Génie des Procédés, UMR 7274 CNRS - University of Lorraine, France

\section{Corresponding Author}

Henri AZAIIS

INSERM U 703

Lille University Hospital

152, rue du Dr. Yersin

59120 LOOS- France

henriazais@gmail.com 


\section{INTRODUCTION}

Ovarian cancer is the leading cause of death from gynecological cancer worldwide (PMID:19592450, PMID:21685461). Unfortunately, the majority of women present with advanced disease with little prospect for cure. Moreover, there remains a significant risk for recurrence and resistance to therapy, and therefore, there is an urgent need to improve the current treatment options. Indeed, there have been some advances in surgical and chemotherapeutic strategies, but these approaches have led to only minor improvements in outcome (PMID: 19592450). As most ovarian cancers are classified as epithelial, the peritoneal cavity should be treated as an entire organ ${ }^{[1]}$. Actually, the treatment of peritoneal lesions remains the optimal treatment of epithelial ovarian cancer, as $60 \%$ of women treated by complete cytoreductive surgery and platinum-based chemotherapy (cisplatin and carboplatin) will develop recurrences ${ }^{[2]}$. However, surgery alone is insufficient to control the microscopic peritoneal disease. In this regard, targeted therapies based on agents specifically directed to overexpressed receptors, or to selected molecular targets, are both promising targets of clinical treatment. For instance, overexpression of folate receptor- $\alpha$ (FRa) on the surface of the vast majority of epithelial ovarian cancers makes this receptor an excellent "tumor-associated antigen" (PMCID: PMC3917542) for targeting most of gynecologic malignancies ${ }^{[3]}$.

Fischer 344 rat is a well-known animal model for studying peritoneal metastasis in advanced ovarian cancer. It is a syngeneic model obtained by the inoculation of a cell suspension of NuTu-19 cells ${ }^{[4]}$. NuTu-19 is a syngeneic adenocarcinoma used to develop ovarian cancer in an immunocompetent rat model ${ }^{[4]}$. It is a poorly differentiated adenocarcinoma originally derived from a female athymic mouse after injection of Fischer 344 ovarian surface epithelial cells that spontaneously underwent malignant transformation in vitro.

Peritoneal cavity should be treated as an entire organ ${ }^{[1]}$, and the treatment of peritoneal lesions remained a strong factor for the treatment of epithelial ovarian cancer, as $60 \%$ of 
women treated by the association of complete cytoreductive surgery and platinum-based chemotherapy will develop recurrences ${ }^{[2]}$. Surgery alone is insufficient to control the microscopic peritoneal disease. Chemotherapy and targeted therapy aim to improve cytoreductive strategy in order to decrease this high recurrence rate.

Many publications focused on targeted therapy to improve the treatment efficiency treatment and to decrease its side effects. Folate receptor alpha (FRa) is one of the most promising target to develop targeted therapy in gynecologic malignancies ${ }^{[3]}$.

The aim of this study is to investigate the abilities of this animal model to evaluate folatetargeted therapy in preclinical studies.

\section{MATERIAL AND METHODS}

\section{Animals}

Pathogen-free Fischer 344 female rats (140 to $160 \mathrm{~g}$ ) were obtained from Harlan Laboratories (Gannat, France). They were housed in a pathogen-free animal facility and given commercial basal diet and water ad libitum. The protocol was approved by the Committee on the Ethics of Animal Experiments ("Departement Hospitalo-Universitaire de Recherche Expérimentale", University of Lille, France, $n^{\circ}$ 59-350120).

\section{Model of peritoneal carcinomatosis}

NuTu-19 cells were cultured in DMEM (Gibco Life Technologies, Grand Island, NY, USA) supplemented with $10 \%$ heat-inactivated fetal bovine serum, penicillin $1 \%$ and streptomycin $1 \%$. Cell culture plates were incubated under standardized conditions ( $5 \%$ carbon dioxide, $100 \%$ humidity, $37^{\circ} \mathrm{C}$ ). After harvesting the NuTu-19 cells with $0.25 \%$ trypsin (Gibco Life Technologies, Grand Island, NY, USA), they were washed with Dulbecco's phosphatebuffered saline (PBS, Gibco Life Technologies, Grand Island, NY, USA) and counted. Viability was assessed using trypan blue exclusion. With a minimum of $90 \%$ survival, $10^{6}$ cells $\mathrm{mL}^{-1} \mathrm{PBS}$ were injected intraperitoneally in the Fischer rats. Small nodules up to $2 \mathrm{~mm}$ 
form along the peritoneal lining of the abdominal wall, pelvis, and omentum with hemorrhagic ascite.

FR $\alpha$ expression by NuTu-19 cells in vitro by immunofluorescence. "Cytospin", protocole.

Cells $\left(10^{5}\right)$ were diluted in $1 \mathrm{~mL}$ of PBS. Slides and filters were placed into appropriate slots in the cytospin. Then, the samples were spun for 4 min at $750 / \mathrm{min}$. Each slide was examined under the microscope to ensure that the cells have been intact. Finally, the slides were airdried for $24 \mathrm{~h}$ at room temperature. Cells were marked with Dakopen ${ }^{\circledR}$ (Dako SA, Trappes, France) before the application of ethanol $80 \%\left(15 \mathrm{~min}\right.$ at $\left.4^{\circ} \mathrm{C}\right)$ and then rinsed with PBS $(30$ min). PBS tween $201 \%$ was the applied for $5 \mathrm{~min}$ at room temperature. Slides were rinsed again with PBS (5min) before the application of primary antibody FL-257 (Santa Cruz Antibody ${ }^{\mathrm{TM}}$ ) in a 1:200 dilution overnight at $4^{\circ} \mathrm{C}$. The day after, slides were rinsed with PBS (15 $\mathrm{min}$ ) and were incubated with secondary antibody (Alexa Fluor® 488 Dye, donkey antirabbit, Life Technologies ${ }^{\mathrm{TM}} 1 / 300^{\mathrm{e}}$ ) for one hour at room temperature. Slides were finally mounted with immunomount + DAPI (Vectashield mounting medium for fluorescence with DAPI, Vector Laboratories ${ }^{\mathrm{TM}}$ ) and coverslipped 30 minutes before their observation by confocal microscopy.

\section{In vitro folate-targeted compound uptake by NuTu-19 cells}

To assess the property of FRa to incorporate folate-targeted compound, we used a folatetargeted photosensitizer (PS): $\quad \mathrm{N}$-\{2-[2-(2-aminoethoxy)ethoxy]ethyl\}folic acid\}-4carboxyphenylporphyrin (called Porph-s-FA) (generous gift from Dr Céline Frochot, LRGP, UMR 7274 CNRS - University of Lorraine, France). The synthesis has been described by Schneider et al. ${ }^{[5]}$ 
We designed a protocol adapted from Schneider et al. ${ }^{[5]}$. Cells $\left(5 \times 10^{4}\right.$ cells $\left./ \mathrm{mL}\right)$ were inoculated in $25 \mathrm{~cm}^{2}$ plastic tissue culture flasks and incubated for $72 \mathrm{~h}$ for proper attachment to the substratum. SKOV-3, OVCAR-3, IGROV-1, commonly used as ovarian cancer cell lines, were used as positive control, as it has already been shown that they express FR ${ }^{[6,7]}$. The cells were then exposed (group B) or not (Group A - control) to a folate-targeted photosensitizer (Porph-s-FA at $10^{-5} \mathrm{M}$ ) in DMEM supplemented with $10 \%$ heat-inactivated fetal bovine serum, penicillin $1 \%$ and streptomycin during $24 \mathrm{~h}$. After incubation with the photosensitizer (PS) sheltered from light exposure, the cells were washed twice in PBS, harvested by enzymatic disaggregation (Trypsin-EDTA). After, the cells were washed in icecold PBS, and centrifuged. Cells bullets were included in paraffin.

Cell bullet sections were fixed on glass slides. They were deparaffinized with xylene, rehydrated through a graded series of ethanol and rinsed in distilled water. Slides were then mounted with DAPI (Vectashield mounting medium for fluorescence with DAPI, Vector Laboratories $^{\mathrm{TM}}$ ) and coverslipped. Slides preparation was performed under dim light.

The fluorescence emission from the drug-loaded cells was observed with confocal microscopy). Slides were examined with an inversed confocal microscope Zeiss LSM 710 (Carl Zeiss ${ }^{\mathrm{TM}}$, Jena, Germany), with 10x/0.3 and 40x/1.3 magnification. ZEN 2010 software (Zeiss Efficient Navigation, Carl Zeiss ${ }^{\mathrm{TM}}$, Jena, Germany) was used for pictures acquisition. To observe the Porph-s-FA specific fluorescence (maximum emission wavelength $\lambda_{\mathrm{em}}=650$ $\mathrm{nm}$ ), we excited the compound using a laser emitting at $\lambda_{\mathrm{ex}}=405 \mathrm{~nm}$. Care was taken to maintain cells under dark conditions when possible.

\section{Determination of in vivo $\mathrm{FR} \alpha$ tissue expression by immunohistochemistry}

Two primary antibodies (Santa Cruz Biotechnology ${ }^{\mathrm{TM}}$ and Antibodies-online ${ }^{\mathrm{TM}}$ ) were previously tested and adjusted on human high grade serous ovarian carcinoma used as a positive control. In our protocol, thanks to its best staining quality, we used Santa Cruz Antibody $^{\mathrm{TM}}\left(\mathrm{FL}-257^{\circledR}\right)$. 
Tissue sections were fixed on glass slides. They were deparaffinised with xylene, rehydrated through a graded series of ethanol and rinsed in distilled water. Antigen retrieval was achieved by heating in EDTA buffer solution at $\mathrm{pH}=8$ for $9 \mathrm{~min}$ at $98^{\circ} \mathrm{C}$. Slides were cooled down to room temperature and rinsed with PBS. After blocking endogenous peroxidase in $3 \% \mathrm{H}_{2} \mathrm{O}_{2}$ in PBS for $15 \mathrm{~min}$, sections were pre-treated by avidin/biotin reagents to reduce non-specific background. Sections were incubated with the primary antibody FL-257 (Santa Cruz Antibody ${ }^{\mathrm{TM}}$ ) for $60 \mathrm{~min}$ in a 1:1000 dilution at room temperature. After washing with PBS, sections were incubated with secondary biotinylated anti-rabbit antibody. Peroxidase activity was visualized with 3,3-diaminobenzidine and slides were counterstained with haematoxylin, mounted with mounting medium and coverslipped. All sections have been reviewed by a senior pathologist.

\section{RESULTS}

\section{Obtention of peritoneal carcinomatosis model}

Figure 1

\section{FR $\alpha$ is expressed by NuTu-19 cells in vitro.}

We have observed the receptor expression in vitro by NuTu-19 cells. We show here by Cytospin techniques that FRa expression (Green) in NuTu-19 cells is homogeneous and mainly located on the cells membrane, as expected while FR $\alpha$ is a membrane-anchored protein. Cell nuclei appear in blue after DAPI application (Figure 2).

\section{FR $\alpha$ expression allows the incorporation of folate-targeted compounds.}

To assess the ability of the receptor described previously to allow cytoplasmic incorporation of folate-targeted compounds, ovarian cancer cell lines were incubated in a medium containing the folate-targeted photosensitizer. We have observed by confocal microscopy, as 
previously described a high intensity staining for FR $\alpha$ expression by NuTu-19, SKOV-3 and IGROV-1 cell lines. These experiments are in agreements with those previously described ${ }^{[6,7]}$. The intensity of the staining for the expression of the receptor by OVCAR-3 is weak. As described previously, the expression of FRa is mainly membranous.

We observed a positive correlation between intensity of receptor expression and a specific intracellular red signal corresponding to endocytosis vesicles containing the photosensitizer (Porph-s-FA) (Figure 3). This signal is absent in cells of control groups cultured without folate-targeted photosensitizer. This observation is coherent with mechanisms commonly described showing that FR $\alpha$ allows cytoplasmic internalisation of folate by endocytosis ${ }^{[8,9]}$.

\section{Expression of FRa in vivo}

To assess the specificity of FR expression by tumor tissue, immunohistochemistry techniques were used to determine the specific expression of the receptor in several organs of the abdominal cavity. Ovary, peritoneum, small intestine, colon, liver, kidney and tumor tissue have been examined. Ovary, liver and tumor tissue showed FRa-positive cell contingent (Figure 4). On the contrary, peritoneum, small intestine, colon, kidney were FRanegative tissue (Figure 5).

In the ovary, the expression of FRa is mainly located at the epithelial surface of the organ. In the liver, FRa is expressed by cells located near the endothelium, which may correspond to human hepatic stellate cells.

\section{DISCUSSION}

Female Fischer 344 rat is a commonly used animal model to study peritoneal carcinomatosis of ovarian origin ${ }^{[4]}$. FR $\alpha$ is one of the most promising target for treatment of ovarian cancer ${ }^{[9-}$ 
${ }^{12]}$. Our results demonstrate that NuTu-19 cells express FR $\alpha$ and that folate-targeted therapy could be evaluated using this animal model in further preclinical studies.

FRa is overexpressed by $40 \%$ of solid tumor, in particular those derived from epithelial tissue of ovaries, breast, kidney and lung ${ }^{[8]} .72-100 \%$ of ovarian carcinoma overexpress this receptor ${ }^{[3,8,13-15]}$, in particular the serous carcinoma ${ }^{[3]}$. According to Crane et al., $81.8 \%$ of serous ovarian carcinoma overexpress $\mathrm{FRa}$, compared to $39.9 \%$ of the mucinous carcinoma [12].

FRa is absent in the majority of healthy tissue ${ }^{[14,16]}$, thus representing a promising target for ovarian cancer targeted therapy. Furthermore, It has been proven that receptor expression was similar between primary tumor, and peritoneal or nodal metastasis, and recurrences ${ }^{[3]}$. It has also been shown that chemotherapy has no impact on receptor expression by residual disease after comparison between lesion sampled during cytoreductive surgery performed before or after the completion of chemotherapy ${ }^{[12,17]}$. It should be possible to undertake a therapy targeted by folate after the obtainment of the histological proof of FRa expression and then to propose this strategy at different stages of the evolution of the disease. Moreover FRa has a wide expression distribution within several tumor types. In this regard, it allows one to develop folate targeted therapy for others indications, such as endometrial cancer ${ }^{[17]}$.

In human, FRa is highly selective for ovarian cancer peritoneal metastasis ${ }^{[3]}$. Our observations suggest that its expression in a rat model is quite similar. We observed no expression of the receptor in small intestine, colon, kidney, or normal peritoneum. We observed an expression on the ovarian epithelial surface and by ovarian intraparenchymal cells contingents. This observation is in agreement with conclusions of Elnakat and Ratnam who reported that FR $\alpha$ is expressed in the germinal epithelium of the ovary, the epithelium of the fallopian tube, the surface epithelium of the uterus, the surface epithelium of the endocervix and the glandular epithelium of the cervix ${ }^{[14]}$. Indeed, O'Shannessy et al. have 
recently confirmed the expression of FRa by the organs of the female genital tractus ${ }^{[15]}$. They have observed that ovaries do not express the receptor under normal conditions, but that the salpinx epithelium does. According to the authors, those findings are concordant with the hypothesis that epithelial ovarian cancer origin derives from the tubal epithelium. This suggests that FR $\alpha$ expression by epithelial ovarian cancer comes from the tumor cells which express the receptor and have so an advantage for proliferation, more than an aberrant expression resulting for their cancerous transformation ${ }^{[15]}$. In the liver, we observed the expression of $\mathrm{FRa}$ in cells near the endothelium and which may correspond to human hepatic stellate cells. Our data suggest that tissue expression of FR $\alpha$ is quite similar in both human and female Fischer 344 rat models. The expression of FR $\alpha$ by the ovaries does not pose a problem for the evaluation of treatment as this organ is remove during cytoreduction surgery for ovarian cancer and no conservation is undertaken in this context. The expression of FR $\alpha$ observed in the liver is interesting and warrants further investigation to determine if this could have significant consequence in case of folate-targeted therapy.

As stated by Elnakat and Ratnam, folate receptor is a promising target among available tumor targets and markers as it present certain distinctive advantages ${ }^{[14]}$ :

- It binds to an innocuous small molecule (folic acid) that is amenable to chemical conjugation with other molecules through its $\gamma$-carboxyl group without decreasing its binding affinity,

- FR quantitatively recycles between the cell surface and intracellular compartments to effectively allow internalizing receptor-bound folate/antifolate compounds and folate conjugates,

- FR expression in most proliferating normal tissues is restricted to the luminal surface of certain epithelial cells where it is inaccessible to the circulation whereas it is 
consistently expressed in specific types of major malignant tumors and leukemic cells where it is accessible via the circulation.

Folate receptor molecular targeting for diagnosis (imaging,...) or therapy (chemotherapy I radiotherapy) is a hot topic of research for more than twenty years ${ }^{[18]}$. However, majority of data regarding drug delivery using this target are available from in vitro studies. Data resulting from in vivo evaluations are rare ${ }^{[19]}$. This is partly due to the absence of validated animal models. It is essential to have a precise knowledge of receptor expression by the target-tissue ${ }^{[17]}$.

Here, we have demonstrated that NuTu-19 cells express FR in vitro and in vivo. As already shown by several authors who have stated that membrane anchored FR $\alpha$ can mediate internalization of receptor-bound folate compounds and folate conjugates [9,14,20], we demonstrated intracellular incorporation of a folate-targeted photosensitizer by endocytosis. By using a murine model (Female Nu-Nu mice injected IP with SKOV-3 cells), Werner et al. demonstrate that folate-targeted nanoparticles were more effective than non-targeted nanoparticles in folate-receptor overexpressing ovarian cancer cell ${ }^{[6]}$.

A rat model allows studying invasive procedures (surgery, photodynamic therapy,...) associated with folate-targeted therapy more easily than a mouse model in the field of epithelial ovarian carcinomatosis.

\section{CONCLUSION}

Female Fischer 344 rat is an inexpensive validated reproducible and efficient preclinical model to study ovarian peritoneal carcinomatosis folate-targeted therapies.

\section{CONFLICTS OF INTEREST}

The authors report no conflict of interest 


\section{ACKNOWLEDGMENT}

This research was supported by SIRIC ONCOLille, Grant INCa-DGOS-Inserm 6041.

Authors want to thank Professor Claude-Alain Maurage team for histological slides realisation, particularly Marie-Héléne Gevaert and Rose-Marie Siminski.

\section{REFERENCES}

1. Elias D, Goéré D, Dumont F, Honoré C, Dartigues $P$, Stoclin A, et al. Role of hyperthermic intraoperative peritoneal chemotherapy in the management of peritoneal metastases. Eur $\mathrm{J}$ Cancer Oxf Engl 1990 2014;50(2):332-40.

2. Al Rawahi T, Lopes AD, Bristow RE, Bryant A, Elattar A, Chattopadhyay S, et al. Surgical cytoreduction for recurrent epithelial ovarian cancer. Cochrane Database Syst Rev 2013;2:CD008765.

3. Kalli KR, Oberg AL, Keeney GL, Christianson TJH, Low PS, Knutson KL, et al. Folate receptor alpha as a tumor target in epithelial ovarian cancer. Gynecol Oncol 2008;108(3):619-26.

4. Rose GS, Tocco LM, Granger GA, DiSaia PJ, Hamilton TC, Santin AD, et al. Development and characterization of a clinically useful animal model of epithelial ovarian cancer in the Fischer 344 rat. Am J Obstet Gynecol 1996;175(3 Pt 1):593-9.

5. Schneider R, Schmitt F, Frochot C, Fort Y, Lourette N, Guillemin F, et al. Design, synthesis, and biological evaluation of folic acid targeted tetraphenylporphyrin as novel photosensitizers for selective photodynamic therapy. Bioorg Med Chem 2005;13(8):2799-808.

6. Werner ME, Karve S, Sukumar R, Cummings ND, Copp JA, Chen RC, et al. Folate-targeted nanoparticle delivery of chemo- and radiotherapeutics for the treatment of ovarian cancer peritoneal metastasis. Biomaterials 2011;32(33):8548-54.

7. Müller C, Schibli R, Krenning EP, Jong M de. Pemetrexed Improves Tumor Selectivity of 111 InDTPA-Folate in Mice with Folate Receptor-Positive Ovarian Cancer. J Nucl Med 2008;49(4):623-9.

8. Parker N, Turk MJ, Westrick E, Lewis JD, Low PS, Leamon CP. Folate receptor expression in carcinomas and normal tissues determined by a quantitative radioligand binding assay. Anal Biochem 2005;338(2):284-93.

9. Sudimack J, Lee RJ. Targeted drug delivery via the folate receptor. Adv Drug Deliv Rev 2000;41(2):147-62.

10. Itamochi $\mathrm{H}$, Kigawa J. Clinical trials and future potential of targeted therapy for ovarian cancer. Int J Clin Oncol 2012;17(5):430-40.

11. Kelemen LE. The role of folate receptor $\alpha$ in cancer development, progression and treatment: Cause, consequence or innocent bystander? Int J Cancer 2006;119(2):243-50.

12. Crane LMA, Arts HJG, Oosten M, Low PS, Zee AGJ, Dam GM, et al. The effect of chemotherapy on expression of folate receptor-alpha in ovarian cancer. Cell Oncol 2011;35(1):9-18. 
13. Markert S, Lassmann S, Gabriel B, Klar M, Werner M, Gitsch G, et al. Alpha-folate Receptor Expression in Epithelial Ovarian Carcinoma and Non-neoplastic Ovarian Tissue. Anticancer Res 2008;28(6A):3567-72.

14. Elnakat $\mathrm{H}$, Ratnam $\mathrm{M}$. Distribution, functionality and gene regulation of folate receptor isoforms: implications in targeted therapy. Adv Drug Deliv Rev 2004;56(8):1067-84.

15. O'Shannessy DJ, Somers EB, Smale R, Fu Y-S. Expression of folate receptor- $\alpha$ (FRA) in gynecologic malignancies and its relationship to the tumor type. Int J Gynecol Pathol Off J Int Soc Gynecol Pathol 2013;32(3):258-68.

16. Antony AC. Folate Receptors. Annu Rev Nutr 1996;16(1):501-21.

17. Despierre E, Lambrechts S, Leunen K, Berteloot P, Neven P, Amant F, et al. Folate receptor alpha (FRA) expression remains unchanged in epithelial ovarian and endometrial cancer after chemotherapy. Gynecol Oncol 2013;130(1):192-9.

18. Leamon CP, Low PS. Delivery of macromolecules into living cells: a method that exploits folate receptor endocytosis. Proc Natl Acad Sci 1991;88(13):5572-6.

19. Leamon CP, Low PS. Folate-mediated targeting: from diagnostics to drug and gene delivery. Drug Discov Today 2001;6(1):44-51.

20. Van Dam GM, Themelis G, Crane LMA, Harlaar NJ, Pleijhuis RG, Kelder W, et al. Intraoperative tumor-specific fluorescence imaging in ovarian cancer by folate receptor- $\alpha$ targeting: first inhuman results. Nat Med 2011;17(10):1315-9. 